HELMINTHOLOGIA, 58, 1: 92 - 99, 2021

\title{
First report of Xiphinema diffusum from Pakistan
}

\author{
E. SHOKOOHI ${ }^{1, *}$, K. NASIRA ${ }^{2}$, E. IQBAL ${ }^{2}$, S. HUSSAIN ${ }^{2}$, P. W MASHELA ${ }^{1}$ \\ ${ }^{1}$ Green Biotechnologies Research Centre of Excellence, University of Limpopo, Private Bag X1106, Sovenga 0727, South Africa, \\ E-mail: ebrahim.shokoohi@ul.ac.za; ${ }^{2}$ National Nematological Research Centre, University of Karachi, Karachi, Pakistan
}

Article info

Received June 3, 2020

Accepted September 10, 2020

\section{Summary}

The population of Xiphinema americanum species group was detected from the soil surronding the roots of peach (Prunus persica) during a survey of plant-parasitic nematodes in Gilgit-Baltistan, Pakistan. From the results of the morphological study, the species was identified as $X$. diffusum. Morphometrics of $X$. diffusum generally agree with those of the type species and the topotype specimens. Molecular analysis of $18 \mathrm{~S}$ rDNA of $X$. diffusum from Pakistan indicated two nucleotide differences and $99 \%$ similarity with the Chinese (AM086669) and the Australian (AM086685) population of $X$. diffusum. Phylogenetic analysis of $18 \mathrm{~S}$ rDNA placed the Pakistanis population close to $X$. diffusum from China and Australia. This species is reported for the first time from Pakistan

Keywords: Prunus persica; Xiphinema americanum group; $X$. diffusum; New record

\section{Introduction}

Peach (Prunus persica) is the most important among the stone fruits and can be grown in temperate climates. It is considered native to China and probably developed in Persia. It is a traditional crop of the Northern area of Pakistan and occupies the area of 6,330 hectares, with the production of approximately 36,155 tones in 2013 - 2014. Quetta, Kalat, Peshawar, Swat valley and certain parts of Kohistan hills are the main peach-growing areas. Peach is the second most important fruit (after plum) in Pakistan (Habib, 2015).

The genus Xiphinema Cobb, 1913, belongs to the family Longidoridae Thorne, 1935 (Meyl, 1961) and subfamily Xiphinematinae Dalmasso, 1961, which is a genus of ectoparasitic nematodes commonly known as the dagger nematodes (Whitehead, 1968). A total of 23 nematode species of the genus Xiphinema have so far have been reported from Pakistan. Among them, three species namely, Xiphinema karachiense Nasira, Firoza \& Maqbool, 1992;
X. cynodonti Nasira \& Maqbool 1994 and X. pakistanensis Nasira \& Maqbool, 1998 were described from Pakistan, whereas 20 other species of the genus Xiphinema have been reported as a new record for Pakistan (Shahina et al., 2019). Due to the complexity of the species in the genus, it is imperative that both morphological and molecular characters be used in species identification. The aim of this study was to 1) study $X$. diffusum by morphological and molecular character using $18 \mathrm{~S}$ rDNA.

\section{Materials and Methods}

The soil samples containing the Xiphinema species were taken from the root zone of peach trees in Gilgit-Baltistan, Pakistan. Nematodes were extracted with Cobb's wet sieving techniques. Material collected on a $25 \mu \mathrm{m}$ mesh sieve was placed on a Baermann funnel and nematodes were collected after one day at room temperature. Specimens were transferred to a small amount of water and then killed by heating at $60^{\circ} \mathrm{C}$. Nematodes were fixed in

\footnotetext{
$\overline{*-\text { corresponding author }}$
} 

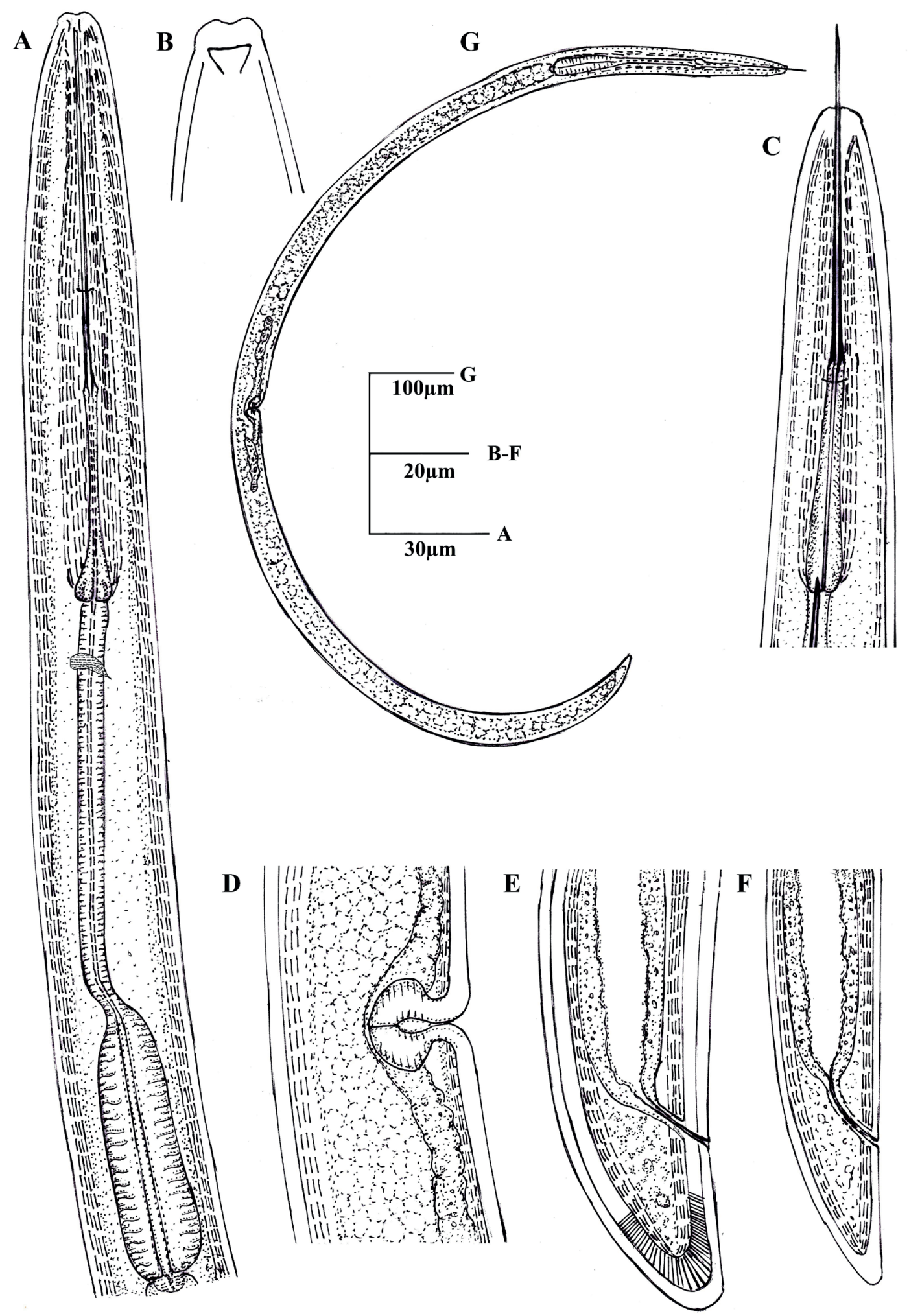

Fig 1. Xiphinema diffusum Lamberti \& Bleve-Zacheo, 1979. A: Anterior end. B: Amphid. C: Odontostyle and odontophore. D: Vaginal region. E: Female posterior end. F: Juvenile posterior end. G: Entire female. 

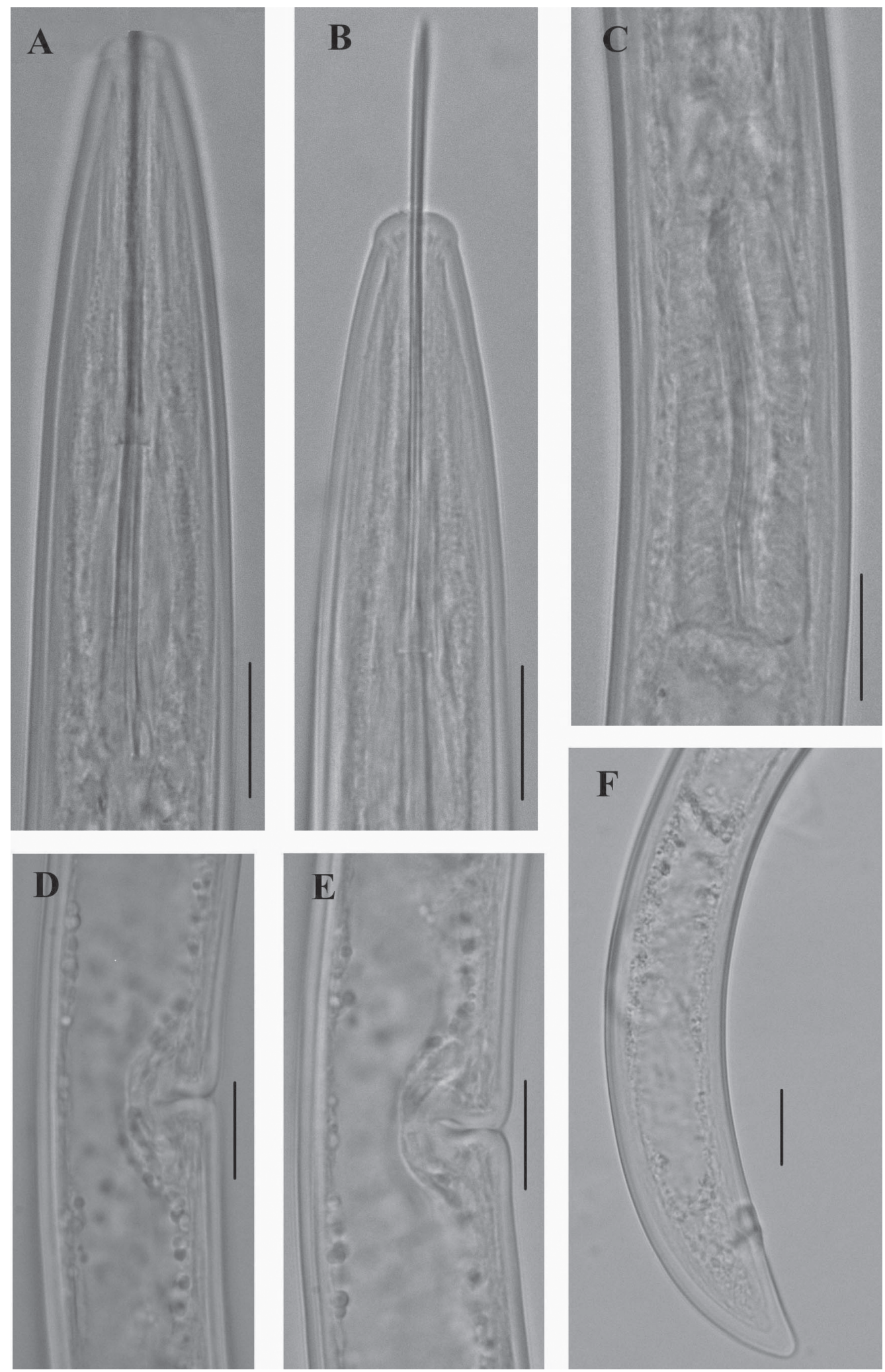

Fig 2. Xiphinema diffusum Lamberti \& Bleve-Zacheo, 1979. A: Anterior end. B: Odontostyle. C: Pharyngeal-intestinal junction. D, E: Vaginal region. E: Female posterior end. (scale bar $=20 \mu \mathrm{m})$ 
TAF than processed into glycerine by the ethanol/glycerine method (Seinhorst, 1959; De Grisse, 1969) and mounted in dehydrated glycerine supported with both minute glass beads and paraffin in glass slides. Observations were made using a DIC microscope (B $x 51$, Olympus Co, Japan). A digital camera was used for measuring, taking LM images and line illustrations of the nematode.

\section{DNA extraction, PCR and phylogenetic analysis}

DNA extraction was done using the Chelex method (Straube \& Juen, 2013). Five specimens were hand-picked with a fine tip needle and transferred to a $1.5 \mathrm{ml}$ Eppendorf tube containing $20 \mu \mathrm{l}$ double distilled water. The nematodes in the tube were crushed with the tip of a fine needle and vortexed. Thirty microliters of $5 \%$ Chelex® 50 and $2 \mu \mathrm{L}$ of proteinase $\mathrm{K}$ were added to each of the microcentrifuge tubes that contained the crushed nematodes and mixed. These separate microcentrifuge tubes with the nematode lysate were incubated at $56^{\circ} \mathrm{C}$ for two hours, and then incubated at $95{ }^{\circ} \mathrm{C}$ for 10 minutes to deactivate the proteinase $\mathrm{K}$ and were spun for 2 min at $16000 \mathrm{rpm}$ (Shokoohi et al., 2019). The supernatant was collected from each of the tubes and stored at $-20^{\circ} \mathrm{C}$. Following this step, the forward and reverse primers, $988 \mathrm{~F}$ (5-ctcaaagattaagccatgc-3) and 1912R (5-ttacggtcagaactaggg-3) were used for PCR amplification of 18S rDNA (Holterman et al., 2006). Amplification was conducted with eight $\mu$ of the DNA template, $12.5 \mu \mathrm{l}$ of 2X PCR Master Mix Red (Promega, USA), one $\mu \mathrm{l}$ of

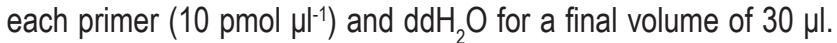
The amplification was processed using an Eppendorf master cycler gradient (Eppendorf, Hamburg, Germany), with the following steps: initial denaturation for $3 \mathrm{~min}$ at $94{ }^{\circ} \mathrm{C}, 37$ cycles of denaturation for $45 \mathrm{~s}$ at $94^{\circ} \mathrm{C}$; $\left(51\right.$ and $55^{\circ} \mathrm{C}$ annealing temperatures for ITS rDNA and 28SrDNA respectively); extension for $45 \mathrm{~s}$ to $1 \mathrm{~min}$ at $72{ }^{\circ} \mathrm{C}$, and finally an extension step of 6 min at $72{ }^{\circ} \mathrm{C}$ followed by temperature on hold at $4{ }^{\circ} \mathrm{C}$. After DNA amplification, $4 \mu \mathrm{l}$ of product from each tube was loaded on a $1.5 \%$ agarose gel in TBE buffer ( $40 \mathrm{mM}$ Tris, $40 \mathrm{mM}$ boric acid, and one mM EDTA) for evaluation of the DNA bands. The bands were stained with RedGel dye and photographed on a UV transilluminator. The amplicons of the genes were stored at $-20^{\circ} \mathrm{C}$. Finally, the PCR products were purified for sequencing by Inqaba Biotech (South Africa). Longidorus biformis (AY283162) based on Van Megen et al. (2009), was selected as the outgroup for 18S rDNA. The ribosomal DNA sequence was analyzed and edited with BioEdit (Hall, 1999) and aligned using CLUSTAL W (Thompson et al., 1994). The length of the alignments were $800 \mathrm{bp}$. Phylogenetic trees were generated using the Bayesian inference method as implemented in the program Mr Bayes 3.1.2 (Ronquist \& Huelsenbeck, 2003). The $G T R+\mid+G$ was selected using jModeltest 2.1.10 (Guindon \& Gascuel, 2003; Darriba et al., 2012). Then, the model was initiated with a random starting tree and run with the Markov chain Monte Carlo (MCMC) for $10^{6}$ generations. The partial $18 \mathrm{~S}$ rDNA of $X$. diffususm was deposited in GenBank under the accession numbers MT422062.
The authors declare that experiments on animals have been followed according to the international, national and institutional guidelines for the care and use of animals and that a research committee has approved the studies at the institution at which the studies were performed (University of Limpopo, South Africa; University of Karachi, Pakistan).

\section{Results}

\section{Xiphinema diffusum Lamberti \& Bleve-Zacheo, 1979}

(Figs. 1\& 2)

\section{Measurement: Table 1.}

Description: Female: The body assumes a ventrally arcuate, open c-shape, or spiral shape when killed by gentle heating. Lip region slightly offset from body contour. Cuticle very finely striated transversely. Amphidial pouches stirrup-shaped with slit-like aperture about half as wide as lip region, occupying $63-65 \%$ of the corresponding diameter. Odontostyle needle-like $85-90 \mu \mathrm{m}$ long and furcate at the base. Odontophore distally flanged, flanges 8 $8.5 \mu \mathrm{m}$ across. Basal ring of guiding apparatus situated $62-76$ $\mu \mathrm{m}$ from anterior end. Nerve ring $160-170 \mu \mathrm{m}$ from anterior end. The first of pharynx about three times than pharyngeal bulb diameter. Vulva a transverse slit, about equatorial and vagina occupying almost $1 / 2$ of the corresponding body diameter. Gonads paired, opposed, reflexed at oviduct; ovaries with a few oogonia with large deformed nuclei, infested with bacteria. Prerectum $104-127 \mu \mathrm{m}$ long, rectum shorter than body diameter at the anus. Tail conoid, with a greater curvature dorsally, rounded terminus, bearing two pairs of caudal pores.

Male: Not found.

Remarks: The specimens of Xiphinema diffusum were collected from the soil around the roots of peach (Prunus persica) from Gilgit-Baltistan, Pakistan. The Pakistanis Xiphinema diffusum resembled the original description of $X$. diffusum described by Lamberti \& Bleve-Zacheo, 1979 except for the lower range of the odontostyle ( $85-90$ vs $73-89 \mu \mathrm{m})$ and tail length (30 - 42 vs 19 $-33 \mu \mathrm{m})$. Besides, compared with the populations from Malawi, Gambia and Madagascar (Lamberti \& Bleve-Zacheo, 1979), they only differ in the tail length ( $30-42$ vs $32 \mu \mathrm{m}$ ). Geographical distribution and biometric variability of $X$. diffusum from Paarl (Western Cape, South Africa), Bet Dagan (Israel) and Mataveri Otai (Eastern Island) have been provided by Lamberti et al. (1991). In comparison with the South African population, Pakistanis species have smaller odontostyle ( $85-90$ vs $90-95 \mu \mathrm{m}$ ), lower c ratio (57-64 vs 65.6 -92.2), smaller body width at the beginning of $J=$ Hyaline portion (12 - 15 vs $15.9-22 \mu \mathrm{m}$ ), the length of the hyaline portion of the tail (J) $(7.5-8.0$ vs $8.8-12.9 \mu \mathrm{m})$ and longer tail $(28-30$ vs $20-26 \mu \mathrm{m})$. The species differs from Israel population only in a lower c ratio (57 - 64 vs 63.8 - 92) and from a population from Eastern Island, it differs only in the smaller tail $(30-42$ vs 
Table 1. Morphometric of Xiphinema diffusum Lamberti \& Bleve-Zacheo, 1979.

Mean $\pm S D$ (range) in $\mu$ m except for $L$.

\begin{tabular}{|c|c|c|c|c|}
\hline & Females $(n=8)$ & $\mathrm{J} 1(\mathrm{n}=1)$ & $\mathrm{J} 2(\mathrm{n}=4)$ & $J 3(n=1)$ \\
\hline $\mathrm{L}$ & $1.736 \pm 103.02(1.6-1.9)$ & (1063) & $\begin{array}{c}1073 \pm 33.5 \\
(1.0-1.1)\end{array}$ & $(1317)$ \\
\hline a & $\begin{array}{c}44.3 \pm 1.8 \\
(42-47)\end{array}$ & 40.8 & $\begin{array}{c}46.1 \pm 0.9 \\
(45.0-47.2)\end{array}$ & 50.6 \\
\hline b & $\begin{array}{c}6.2 \pm 0.5 \\
(5.7-7.1)\end{array}$ & 5.0 & $\begin{array}{c}4.7 \pm 0.4 \\
(4.3-5.3)\end{array}$ & 4.8 \\
\hline c & $\begin{array}{c}60.1 \pm 2.5 \\
(57-64)\end{array}$ & 44.2 & $\begin{array}{c}30.2 \pm 3.5 \\
(28.1-34.8)\end{array}$ & 43.9 \\
\hline$c^{\prime}$ & $\begin{array}{c}1.1 \pm 0.1 \\
(0.9-1.2)\end{array}$ & 1.7 & $\begin{array}{c}2.3 \pm 0.5 \\
(1.9-3.0)\end{array}$ & 1.6 \\
\hline V & $\begin{array}{c}52.4 \pm 0.9 \\
(52-54)\end{array}$ & - & - & - \\
\hline Odontostyle & $\begin{array}{c}87.5 \pm 1.7 \\
(85-90)\end{array}$ & 62 & $\begin{array}{c}62.2 \pm 1.8 \\
(60-64)\end{array}$ & 71 \\
\hline Odontophore & $\begin{array}{c}52.8 \pm 1.1 \\
(51-54)\end{array}$ & 42 & $\begin{array}{c}37.2 \pm 0.8 \\
(36-38)\end{array}$ & 42 \\
\hline Total stylet & $\begin{array}{c}140 \pm 0 \\
(138-144)\end{array}$ & 104 & $\begin{array}{l}99.5 \pm 1.1 \\
(98-101)\end{array}$ & 113 \\
\hline Replacement odontostyle & - & 72 & $\begin{array}{l}74 \pm 3.1 \\
(70-78)\end{array}$ & 86 \\
\hline Oral aperture to guiding ring & $\begin{array}{c}68.3 \pm 5.41 \\
(62-76)\end{array}$ & 46 & $\begin{array}{c}47.2 \pm 1.9 \\
(45-50)\end{array}$ & 57 \\
\hline Pharyngeal bulb length & $\begin{array}{c}66.8 \pm 2.6 \\
(64-79)\end{array}$ & 44 & $\begin{array}{c}51.5 \pm 4.0 \\
(46-57)\end{array}$ & 56 \\
\hline Pharyngeal bulb width & $\begin{array}{c}19.7 \pm 0.6 \\
(19-21)\end{array}$ & 18 & $\begin{array}{c}15.7 \pm 0.4 \\
(15-16)\end{array}$ & 18 \\
\hline Body diameter at lip region & $\begin{array}{c}11.8 \pm 0.7 \\
(11-13)\end{array}$ & 9 & $\begin{array}{c}8.5 \pm 0.5 \\
(8-9)\end{array}$ & 10 \\
\hline Body diameter at guiding ring & $\begin{array}{c}27.7 \pm 1.1 \\
(26-29)\end{array}$ & 20 & $\begin{array}{c}18.5 \pm 0.5 \\
(18-19)\end{array}$ & 23 \\
\hline Body diameter at base of pharynx & $\begin{array}{c}34.8 \pm 1.1 \\
(33-36)\end{array}$ & 26 & $\begin{array}{c}23.5 \pm 0.5 \\
(23-24)\end{array}$ & 29 \\
\hline Body diameter at vulva & $\begin{array}{c}37.8 \pm 3.4 \\
(34-44)\end{array}$ & - & - & - \\
\hline Body diameter at anus & $\begin{array}{c}26.8 \pm 1.3 \\
(25-28)\end{array}$ & 14 & $\begin{array}{l}15 \pm 0.70 \\
(14-16)\end{array}$ & 19 \\
\hline Body diameter at beginning of $\mathrm{J}$ & $\begin{array}{c}13.3 \pm 1.1 \\
(12-15)\end{array}$ & 6 & $\begin{array}{c}5.7 \pm 0.4 \\
(5-6)\end{array}$ & 7 \\
\hline Genital Primordium (GP \%) & - & 54.5 & $\begin{array}{c}53.0 \pm 2.2 \\
(49.5-55.5)\end{array}$ & 52.0 \\
\hline Hyaline portion of tail (J) & $\begin{array}{c}7.9 \pm 0.2 \\
(7.5-8.0)\end{array}$ & 6 & $\begin{array}{c}7.0 \pm 0.70 \\
(6-7)\end{array}$ & 7 \\
\hline Tail & $\begin{array}{c}35.5 \pm 5.5 \\
(30-42)\end{array}$ & 24 & $\begin{array}{l}29 \pm 0.8 \\
(28-30)\end{array}$ & 30 \\
\hline
\end{tabular}




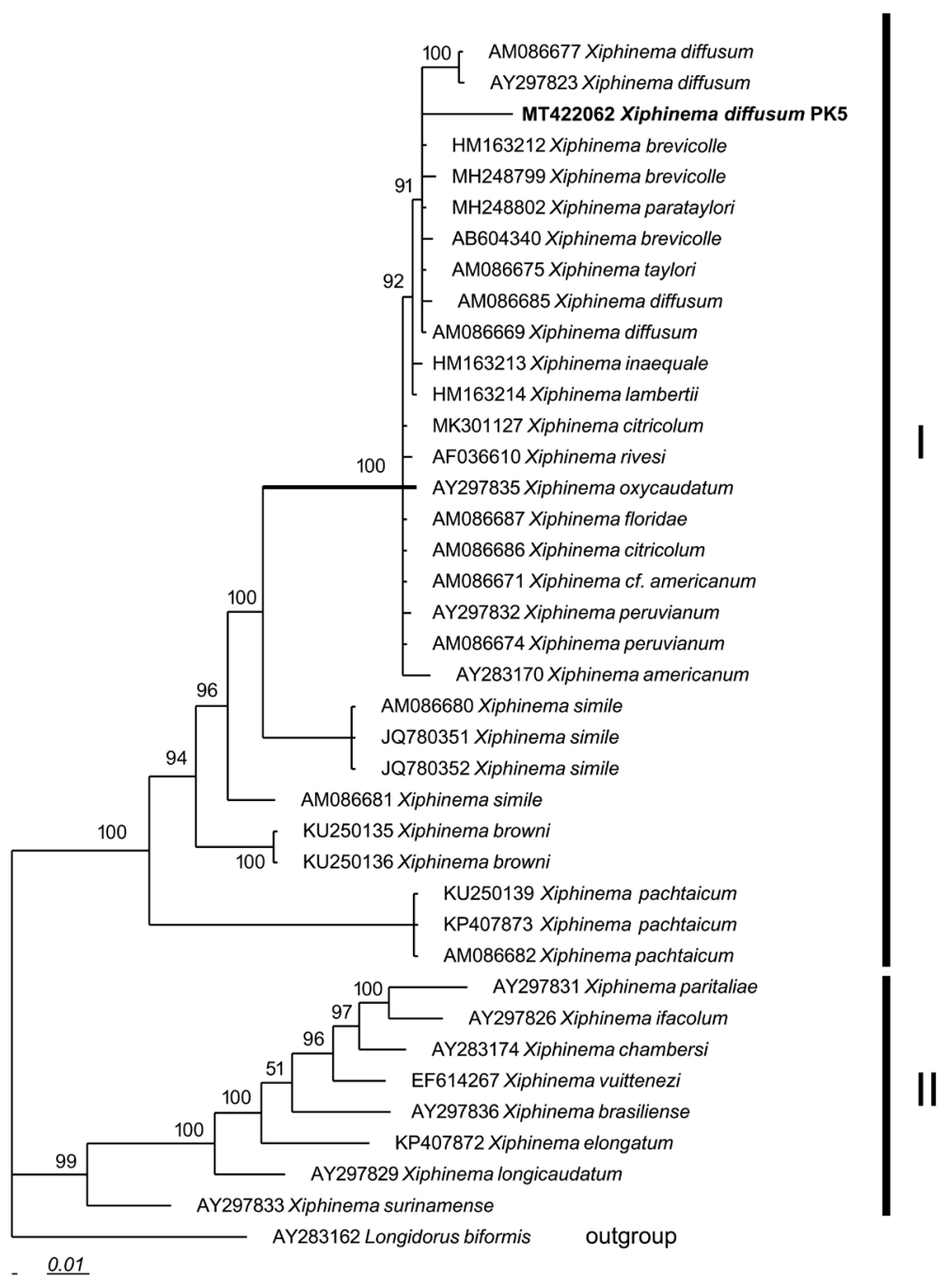

Fig 3. MrBayes tree of the Xiphinema diffusum populations from GenBank and newly sequenced from Pakistan based on the 18S rDNA gene under GTR+I+G model (($\operatorname{lnL}=4705.5454 ; \mathrm{AIC}=9583.090780 ;$ freqA $=0.2774 ;$ freqC $=0.2134 ;$ freqG $=0.2590 ;$ freqT $=0.2502 ; R(a)[A C]=1.2052 ; R(b)[A G]=2.9726 ; R(c)[A T]=1.6440 ; R(d)$ $[C G]=0.4703 ; R(e)[C T]=4.9113 ; R(f)[G T]=1.0000 ; p$-inv = 0.5080; gamma shape $=0.2770)$.

$23.5-27.1 \mu \mathrm{m})$. From a population of $X$. diffusum studied by Luc et al., (1998), they differ in the odontostyle length ( $85-90$ vs 90 $-95 \mu \mathrm{m})$. Compared with a Portuguese population of $X$. diffusum (Lamberti et al., 1994), they differ in body length $(L=1.6-1.9 \mathrm{vs}$ $1.7-2.2 \mathrm{~mm})$, $V$ value $(\mathrm{V}=51.7-54$ vs $47-50)$, body width at beginning of $\mathrm{J}(12-15 \mathrm{vs} 14-20 \mu \mathrm{m})$ and in hyaline portion of tail $(\mathrm{J}=7.5-8.0$ vs $8-12 \mu \mathrm{m})$. This species is reported for the first time from Pakistan.

\section{Phylogenetic analysis}

The Bayesian inference tree of $18 \mathrm{~S}$ rDNA of Xiphinema (Fig. 3) grouped them into two clades including I) $X$. diffusum, $X$. brevicolle, $X$. taylori, $X$. paratylori, $X$. inaequale, $X$. lamberti, $X$. citricolum, $X$. rivesi, $X$. oxycaudatum, $X$. floridae, $X$. cf. americanum, $X$. peru- vianum, $X$. simile, $X$. browni and $X$. pachtaicum with 100 posterior probability; and II) $X$. paritaliae, $X$. ifacolum, $X$. chambersi, $X$. vuittenezi, $X$. brasiliense, $X$. elongatum, $X$. longicaudatum and $X$. surinamense with 99 posterior probability. Nblast of $18 \mathrm{~S}$ rDNA of $X$. diffusum revealed two nucleotides differences with the same species of Chinese (AM086669) and Australian (AM086685) population with $99 \%$ similarity. The Pakistanis speciemns of $X$. diffusum placed in Clade I with 100 posterior probability, close to the same species from Brasil (AM086677; AY297823), along with two other sequences of Xiphinema diffusum from China (AM086669) and Australia (AM086685) with 91 posterior probability. In addition, our sequence of $18 \mathrm{~S}$ rDNA of $X$. diffusum grouped with $X$. brevicolle from Czech Republic (HM163212) with $91 \%$ posterior probability. 


\section{Discussion}

This study is the first report of the occurrence of $X$. diffusum in Pakistan to date. Twenty-three species of Xiphinema have been reported from Pakistan. Xiphinema diffusum, including our specimens belong to the $X$. brevicolle-subgroup, which includes five species namely $[X$. brevicolle, $X$. diffusum, $X$. inaequale, $X$. incognitum, and $X$. taylori] (Sakai et al., 2011). However, the validity of the respective species is a different matter. Appropriate establishment of subgroups within the $X$. americanum-group will contribute to a more feasible identification process of the member species and requires further research. In the original description for X. diffusum, Lamberti \& Bleve-Zacheo (1979) indicated that it differs with $X$. brevicolle in smaller size, less expanded lip region, shorter odontostyle and more rounded tail. In addition, the further studies also indicated that the species such as $X$. brevicolle and $X$. diffusum are very similar which distinguished by only minute morphological differences (Brown \& Halbrendt, 1997). The previous molecular study revealed that $X$. diffusum and $X$. brevicolle are close to each other (Sakai et al., 2011; Zeng et al., 2016). The result of the present study indicated that $X$. diffusum grouped with $X$. brevicolle. However, they differ in body length $(1.6-1.9$ vs $1.7-2.2 \mathrm{~mm}$ ) and total stylet length ( $138-144$ vs $144-173 \mu \mathrm{m})$ (see Sakai et al., 2011). Besides, $X$. brevicolle was reported from Pakistan in associated with apple and citrus trees (Lamberti et al., 1987) and banana (Pathan et al., 2004). Although the morphometrics of $X$. brevicolle was not provided by Lamberti et al. (1987), however, our speciemns differ from those studied by Pathan et al. (2004) in stylet length ( $138-144$ vs $98-123.6 \mu \mathrm{m}$ ) and c value (57-64 vs $27-41)$.

\section{Conclusion}

In this study, specimens of $X$. diffusum, present in the root zone of peach in Pakistan, were identified using morphological and $18 \mathrm{~S}$ rDNA. Despite the close relationship of $X$. brevicolle and $X$. diffusum using $18 \mathrm{~S}$ rDNA marker and phylogenetic analysis, their morphometrics suggesting separate species. Although, our specimens belong to the $X$. diffusum and $X$. brevicolle-subgroup, more populations are needed to be studied using other molecular markers to find out the relationship of the above-mentioned species group.

\section{Conflict of Interest}

The authors declare that there is no conflict of interest.

\section{References}

Brown, D.J.F., HaLBRENDT, J.M. (1997): Identification of Xiphinema species. In: Santos, M.S.N.A., AbRantes, I.M.O., Brown, D.J.F. and LEMos, R.J.V.C.M. (Eds) An introduction to virus vector nematodes and their associated viruses. Coimbra, Portugal, Centro de Sis- tematica e Ecologia, Universidade de Coimbra, pp. 177 - 223. Совв, N.A. (1913): New nematode genera found inhabiting freshwater and non-brackish soils. J. Wash. Acad. Sci., 3: 432 - 444. DOI: 10.5962/bhl.part.20323

DarRiba, D., Taboada, G.L., Doallo, R., Posada, D. (2012): jModelTest 2: more models, new heuristics and parallel computing. Nat Methods., 9: 772. DOI: 10.1038/nmeth.2109

DE GRISSE, A.T. (1969): Redescription on modifications de quelques techniques dans l'etude des nematodes phytoparasitaires [Redescription on modifications of some techniques in the study of phytoparasitic nematodes]. Mededelingen van de Rijks-faculteit Landbowwetenschappen Gent., 34: 351 - 369 (In French)

Guindon, S., Gascuel, O. (2003): A simple, fast and accurate method to estimate large phylogenies by maximum-likelihood. Syst Biol., 52: 696 - 704. DOI: 10.1080/10635150390235520

$\mathrm{H}_{\mathrm{AB}} \mathrm{B}$, S. (2015): Peach: queen of fruits. Pakistan Food Journal, retrieved from http://foodjournal.pk/2015/September-October2015/PDF-September-October-2015/Exclusive-on-Peach.

Holterman, M., Van der Wurff, A., Elsen, S., Megen, H., Bongers, T., Holovachov, O., Bakker, J., Helder, J. (2006): Phylum-Wide Analysis of SSU rDNA Reveals Deep Phylogenetic Relationships among Nematodes and Accelerated Evolution toward Crown Clades. Molecular biology and evolution, 23: 1792 - 800. DOI: 10.1093/molbev/msI044

LAMBeRTI, F., BLEVE-ZACheO, T. (1979): Studies on Xiphinema americanum Sensu lato with descriptions of fifteen new species (Nematoda, Longidoridae). Nematol. Medit., 7: 51 - 106

Lamberti, F., Bravo, M. A., Agostinelli, A., Lemos, R.M. (1994): The Xiphinema americanum group in Portugal with description of four new species (Nematoda: Dorylaimida). Nematol. Medit., 22: 189 $-218$

Lamberti, F., Ciancio, A., Agostinelli, A., Coiro, M. I. (1991): Relationship between Xiphinema brivicolle brevicolle and $X$. diffusum, with a redescription of $X$. brivicolle brevicolle and descriptions of three new species of Xiphinema (Nematode: Dorylaimida). Nematol. Mediterr, 19: 311 - 326

Luc, M., Coomans, A., Loof, P. A. A., Baujard, P. (1998): The Xiphinema americanum group (Nematoda: Longidoridae). 2. Observations on Xiphinema brevicollum Lordello \& Da Costa, 1961 and comments on the group. Fundam. Appl. Nematol., 21: 475 - 490 MEYL, A.H. (1961): Die freilebenden Erd- und Süsswassernematoden (Fadenwurmer) [The free-living terrestrial and freshwater nematodes (Threadworm)] In: Die Tierwelt Mitteleuropas. Quelle and Meyer, Leipzig [The wildlife Central Europe. Quelle and Meyer, Leipzig], 164 pp. (In German)

NASIRA, K., FIROZA, K., MAQBOOL, M. A. (1992): Description of Xiphinema karachiense sp. n., and morphometric data on Enchodelus macrodorus (de Man, 1880), Thorne, 1939 (Nematoda: Dorylaimida) from Pakistan. Fundam. Appl. Nematol., 15: 421 - 426

NasiRA, K., MaqBool, M. A. (1994): Xiphinema cynodontis n. sp., (Nematoda: Longidoridae) from Pakistan. Pak. J. Nematol., 12: $99-107$ 
NASIRA, K., MAQBool, M. A. (1998): Description of Xiphinema pakistanensis n. sp., and the male of $X$. oxycaudatum Lamberti \& Bleve-Zacheo, 1979 with observation on X. thornei Lamberti \& Golden, 1986 (Nematoda: Longidoridae) from Pakistan. Pak. J. Nematol., 16: 1 - 12

Ronquist, F., Huelsenbeck, J. (2003): MrBayes 3: Bayesian phylogenetic inference under mixed models. Bioinformatics 19: 1572 - 1574. DOI: 10.1093/bioinformatics/btg180

Sakal, H., TAKerda, A., Mizukubo, T. (2011): First report of Xiphinema brevicolle Lordello et Costa, 1961 (Nematoda, Longidoridae) in Japan. Zookeys, 135: 21 - 40. DOI: 10.3897/zookeys.135.1716 SEINHORST, J.W. (1956): The quantitative extraction of nematodes from soil. Nematologica, 1: 249 - 267. DOI: 10.1163/187529256X00096

Shahina, F., Nasira, K., Firoza, K., ERum Y. I. (2020): Overview of Nematode fauna of Pakistan. Pak. J. Nematol., 37(2): 171 - 243

Shokooh, E., Mashela, P.W., Panahl, H. (2019): Criconema mutabile (Nematoda: Criconematidae) from Iran and South Africa. Biologia, 1 - 11. DOI: 10.2478/s11756-019-00364-2
Straube, D., Juen, A. (2013): Storage and shipping of tissue samples for DNA analyses: A case study on earthworms. Eur J Soil Biol., 57: 13 - 18. DOI: 10.1016/j.ejsobi.2013.04.001 THOMPSON, J.D., HIGGINS, D.G., GIBSON, T.J. (1994): CLUSTAL W: improving the sensitivity of progressive multiple sequence alignment through sequence weighting, position-specific gap enalties and weight matrix choice. Nucleic Acids Res., 22: 4673 - 4680 THORNE, G. (1935): Notes on free-living and plant-parasitic nematodes II. Proc. Entomol. Soc. Wash., 2: 96 - 98

van Megen, H., van den Elsen, S., Holterman, M., Karssen, G., Mooyman, P., Bongers, T., Holovachov, O., Bakker, J., Helder, J. (2009): A phylogenetic tree of nematodes based on about 1200 full-length small subunit ribosomal DNA sequences. Nematology, 11: 927 - 950. DOI: 10.1163/156854109X456862

Zeng, Y., Ye, W., Zhang, Z., Sun, H., Yong, L., Huang, Y., Zhao, K., Liang, H., KeRns, J. (2016): Morphological and molecular characterization of Xiphinema species from Shenzhen, China. Helminthologia, 53 (1): 62 - 75. DOI: 10.1515/helmin-2015-0068 